\title{
XXVIII. On the magnetic polarity of two rocks of basalt near Nürburg in the Eifel, with some observations on the extension of basalt in that district; drawn up from the observations of Bergmeister Schulze of Düren
}

\section{Professor J. Nöggerath}

To cite this article: Professor J. Nöggerath (1830) XXVIII. On the magnetic polarity of two rocks of basalt near Nürburg in the Eifel, with some observations on the extension of basalt in that district; drawn up from the observations of Bergmeister Schulze of Düren , Philosophical Magazine Series 2, 8:45, 174-180, DOI: 10.1080/14786443008675401

To link to this article: http://dx.doi.org/10.1080/14786443008675401

曲 Published online: 13 Jul 2009.

Submit your article to this journal ๘

ЦIl Article views: 2

$Q^{\mathbf{2}}$

View related articles \lceil 
immensely large, will in all probability be greater than $n$, $\phi$ will be greater as $\lambda$ is greater. Therefore $m$ will be less as $\lambda$ is greater. Hence the rays for which $\lambda$ is greatest, that is the least refrangible rays, will be propagated with the greatest velocity. Also the velocity of propagation is independent of the intensity of the rays. These results are conformable with experience.

As $n$ is probably exceedingly small compared with $\frac{x^{2} a^{2}}{\lambda^{2}}$, it is possible that $\lambda$ may have a value much larger than it has for luminous waves, and $\cot \phi$ not change sign in consequence, but become very small. Then $\cos \phi$ would $=0$, and $m=1$ nearly. Thus there may be æthereal undulations much broader than those which cause light, that do not undergo sensible change in their velocity of propagation, as they enter mediums.

XXVIII. On the Magnetic Polarity of two Rocks of Basalt near Nürburg in the Eifel, with some Observations on the extension of Basalt in that district; draton up from the Observations of Bergmeister Schulze of Diiren. By Professor J. NögGerath.*

SINCE the discovery, by Alexander Von Humboldt, of the magneto-polar property of a rock of serpentine on the Haidberg or Heideberg, near Celle, in the country of Baireuth, many other rocks have been found possessed of the same property, viz. : serpentine, and rocks of other kinds, such as hornblende-slate, porphyry, trachyte, basalts, \&c. $\dagger$

It seems, however, to be found only in mountains containing magnetic iron-stone, although the quantity of this admixture in itself does not limit the intensity of this property; as indeed it shows itself with different purely magnetic ironstones in the greatest variety of degrees of strength, and there are some of these which show no magneto-polar action.

Nor does there appear, from all the observations made on magneto-polar rocks and fragments, that there is any regula-

- From Schweigger's Journal.

+ For the discovery of Humboldt and those connected with it, see in particular the Intelligenz Blatt of Jenaer Algemeine Literaturzeitung, 1796, No. 169 , p. 1447; ibid. 1797, No. 38, p. 323; No.68, p. 564 ; and No. 87; p. 722. Neues Bergmann's Journal, i. pp. 257 \& 542. Gren's Neues Journ. d. Chem. u. Phys. iv. Heft i. p. 136. V. Moll's Jahrbuch d. Berg $u$. Hutten Kunde, iii. p. 301. V. Moll's Neues Jahrbuch d. B. u. H. ii. p. 403. Gilbert's Annalen, neue Folge xiv. Heft i. p. 89. Goldfusz and Bischof's Phisik. statist. Beschreibung d. Fichtelgebirges, i. p. 139. and ibid. altere Reihe xviii. p. 297. 
rity in the position of the axes either in one and the same mass of rock in general, or a fixed correspondence, in the position of these axes, with the direction of the strata of the rocks. Individual cases are indeed found in which a number of traversing magnetic axes lie parallel in a rock, and even instances in which their position is in constant correspondence with the direction of the strata of the hills in which they are found ; but there are found in the same rock, besides those parallel axes, others of a deviating position, so much so as to intersect and cross each other, and to meet within the rock with poles of the same description*.

But very recently I received an official report of the magneto-polar property of two basaltic rocks in the Eifel, which may be considered as an extraordinary instance of variety of position of the axes contained in them. On my request to Bergmeister Schulze of Düren to communicate to me his observations on them, I received the following letter from him, which, besides containing the information I sought, gives some other interesting particulars of the district of the Eifel.

I consider these two basaltic rocks as peculiarly adapted for making strict investigations on the polarity of rocks, as they are comparatively small, and may be examined on every side, and the variations of the phænomena are placed close, and yet very conspicuously, together. I shall employ my first leisure for their examination. For the present, a young but distinguished natural philosopher has promised to devote a few days to this purpose during the Easter vacations. If the results turn out generally interesting, I shall publish them. In the mean time the following letter may suffice.

"Düren, 18th February, 1828.

"Since you, my respected friend, consider the discovery I made during my last summer's excursion in the Eifel of some rocks of basalt having magnetic power, sufficiently important to be placed before the public, I shall have the honour to give you a short account of it. I only regret that it cannot be a

- The greatest constancy in the position of magnetic axes in polarizing rocks has probably been observed in that of the above-named Haidberg. But it only requires a close study of the observations made by the last examiners of it, Professors Goldfusz and Bischof, to discover that there must be in this rock also, besides a great number of parallel axes, others of a deviating position; a fact which becomes the more apparent if we compare the description of the properties of the whole rock with the experiments made by Prof. Bischof with detached pieces of it. See Beobachtungen ïber die magnetischen Eigenschaften einiger Gebirgsarten des Fichtelgebirges, by Dr. G. Bischof, in this (Schweigger's) periodical, old series, vol. xviii. p. 297, \&c.) Cormpare also in particular the account accompanying that Essay, and observe that page 324 , line 17 , the word south-west appears instead of south-east; evidently through an error of writing, or of the press.

scientific 
scientific one, as the journey had no scientific object, except as to mining, and a general knowledge of the rocks forming the surface.

"Although an attempt may be made to form several of the groups of basalt, with which the Eifel is scattered over, into lines, there is none so long, and of which the range is so close, as that round the Nürburg, one league and a quarter south of Adenau. Its direction is meridional, with a slight inclination towards the west. It begins in the S. near Bertrich (not far from the Mosel), with the remarkable formation of basalt and scoria, runs by Walmeroth, Ulmen, Horperath, over the high Kellberg, between the villages of Kellberg and Ursfeld, by the Nirburg, the detached group near Adenau, with outliers as far as the Hochthurn and Hasenberg, between Kirchsahr and Altenahr. With the exception of the Hohen-Acht, two leagues S.E. of Adenau, this line includes the highest masses, exceeding all the summits of grauwacké-slate, on which they stand; such are the Hoh-Kellberg, the Niurburg, and the Hochthurn. These cones rise between 1900 and 2000 Prussian feet above the level of the Rhine. There is no other appearance of volcanic origin in the cones of this chain (except at Bertrich and the Maars*) than in the basalts of the Westerwald, Hesse, and Silesia; and their nature would bave remained in doubt if the closely: aggregated and undoubtedly volcanic groups, running in a continuous range from the volcano of Bertrich as far as Hillesheim, did not bear the clearest evidence of it. I will not allude here to the volcanic range accompanying the. Rhine, as it would draw me too far from my object, which is: to show that the line of elevated basaltic cones here described, seven German miles in length, in their position nearly parallel with the magnetic meridian, may bear a relation to the peculiar magnetic property of the rocks of several of the hills of this line. I stood on the Michelstein, a double-pointed hill of basalt; on the northern mountain range of the Eifel, the beautiful semi-circle of the high cones of Hochthurn, Hohen-Acht, Nürburg, Kellberg, and Ahremberg, lay before me. The Nürburg rose in apparently a spiral form, which deception is increased by the ruined tower standing on its summit. Three days after I ascended it, I went up from Adenau as far as the Wimbacher-Höhe, between the village of Wimbach and Nürburg, where a promi-

- The Maars are circular lakes among the grauwacké-slate, with steep banks. Without any visible supply, they orerfow copiously through an aperture in their banks towards the neighbouring valley. Their highest edge is covered partly with a stratum of volcanic grit, mixed with scoria and pieces of alate, masses of augite and pieces of basalt, and partly with an alluvial deposit of trappean substances. 
sing adit has been driven close. It consists of various fragments of rocks, and its course is parallel with the magnetic meridian, and consequently with the group of basalt of Nürburg. The mountain consists of grauwacké-slate, formed of beds of common grauwacké, slaty grauwacké, and clay-slate. By the trials since made, under the name of Katharinengrube, it is found to fall $70^{\circ} \mathrm{S}$; ; a dip which is as little constant as its direction. The great character of the strata is undulation, and the greater declivities run S. and S.E.

" The line on which the three highest cones, the HoheAcht, the Nürburg and the Hoch-Kellberg, are placed, is the south-eastern range of the Eifel, from the southern declivities of which the waters stream towards the Mosel and Rhine, but from the north-western declivity, towards the Ahr.

"It seems as if the basaltic cone of Nürburg had afforded some protection to the grauwacké-slate, as the latter gently rises even to the spot whence the former abruptly ascends. The mass of basalt is indeed small when we consider the view it affords from a distance; but on the other hand the highest cone is surrounded by several smaller ones, some of which, such as the Selberg, at its northern foot, near Guiddebach, equal it in bulk. This Selberg rises from the bottom of the valley without, its top reaching the elevation of the borders of the valley. Other cones of a gray colour lie on the southern declivity of the same valley to the N.E. of the Nïrburg; towards the E., at a distance of about 150 fathoms, rises on the table-land of the mountain chain a low gentle acclivity, with low rocks, called the Stein-Ecke, and a quarter of a German mile, towards the S.W., rises a remarkable cone. From this cone several very small masses of basalt run in a line towards the Nürburg, as it were marking the throwings up of an adit. Except the Stein-Ecke, all these masses of basalt have nothing to distinguish them from others of a similar formation. Looking from the top of the Nürburg, I perceived at first something on the eastern flat hill resembling some unimportant ruins of a building. Instead of ruins, however, I found two insignificant rocks, about half a fathom distant from each other in their diagonats, about one fathom high, and holding each half a square fathom in their base. The south-eastern rock is one fathom long, half a fathom broad; the other to the N.W. a little shorter, but broader. Both rocks are in strata, or rather are separated into thick slabs, as is seen in flinty-slate, which slaty structure is parallel to the long sides. Their dip is twelve hours, and therefore parallel to the basaltic range on which they lie, as well as to that of the metallic ore mentioned above. The separating surfaces fall $73^{\circ} \mathrm{E}$. This inclination

N. S. Vol. 8. No. 45. Sept. 1830.

$2 \mathrm{~A}$ does 
does not seem to be confined to the rocks as far as they are exposed, but probably descends deeper into the mountains, as would seem from an uncovered part I noticed, lower down on the south side. I marked the direction of the slaty beds, and communicated them to the Ober-einfahrer, Mr. Becher of Commern, who accompanied me; on his doing the same, we discovered a difference. Our attention being thus excited, I went round both rocks, and holding the compass everywhere close to them, noted the directions of the needle, as represented in the annexed figure*. The variations of the needle were always sudden and violent, so that its vibrations were few,

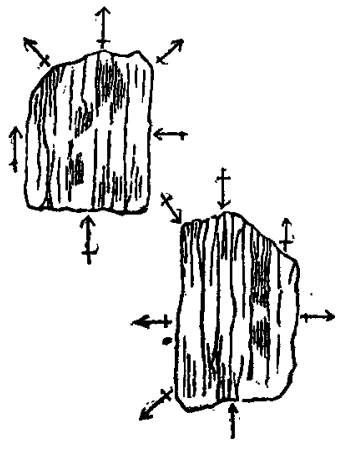
but rapid. The N.W. rock seems to contain a magnetic axis, but not the other; in the meridian it attracts the northern point of the needle, and on the cross line running through the centre, the southern point turns towards the rock.

"The colour of the mass is dark gray, in some parts iron black, on the cross fracture conchoidal, without betraying to the naked eye any foreign admixture, such as magnetic ironstone. It is probable that there are other points about the surrounding basalt hills where the needle would be disturbed; but want of time, and unfavourable weather, prevented my making further experiments.

"From the Nürburg I went to the village of Kellberg, and looked the following day for trachyte porphyry with crystals of albite, about the cone called Freienhäuschen. Here, between the hamlet of Köttelbach and the Hoch-Kellberg, are two cones close together, to the N. the Brink, and to the $\mathrm{S}$. the Frauen, or Freienhäuschen. On the first the mass of porphyry is of two kinds; the one apparently prevailing is of a liver-colour with delicate admixed parts. 'This latter mass is very distinctly formed in strata, and attached to, or more probably inserted in the other, dipping twelve hours, and dipping pretty strongly to the E. Too much engaged in looking for pieces of porphyry with remarkable crystals of albite, I suffered the weak attractive power of the black trachyte to escape my notice, on the spot, not perceiving it till afterwards in some pieces I had taken with me. The strata in the Brink, where

- It need 'perhaps scarcely be noticed, that the arrows in the figure pointing towards the rock indicate a northern, and turned from the rock, a southern attraction, and that the needle lying parallel to the rock is to mark an indifferent position. $-\mathrm{N}$. 
they are perceptible as well as the hills themselves, are meridional; and a quarter of a mile more south, is the pond of Morbruch, a maar of some extent. Schulze."

Addition to the foregoing Article :-On the Magnetic Polarity of two Basaltic Rocks in the Lordship of Schröckenstein. By M. REuss of Berlin, Counsellor of Mines.*

To the very interesting discovery of magnetic polarity in two rocks of basalt near Nüburg in the Eifel, published by Mr. Schulze of Diren, in the Jahrb. der Chem. $u$. Phis. (see the preceding article in the Phil. Mag. and Annals) may be added another made by myself in 1827, near the high Wostrai, in the lordship of Schröckenstein, in the Mittelgebirg.

This high Wostrai forms in itself a small, rather insignificant cone, but which, owing to its high situation, overlooks the whole neighbourhood, and affords an excellent prospect of a great part of the Mittelgebirg on both sides of the Elbe. Its elevation above the river near Aussig may be about 1800 feet. This cone is covered with wood to its summit; and is precipitous on all sides; only the top shows any rock uncovered, and forms a narrow coombe, falling from south to north. In the steeper parts the basalt is separated into tabular masses; these tables, which are about six or eight inches thick, fall four or five hours under nearly $24^{\circ} \mathrm{W}$. On the west, the Wostrai connects itself with the Skala, or rather forms the highest point of it, and runs out in the southern and eastern gentle and well cultivated declivity of the Gemeindeberg; on the east the foot of the cone falls in the equally well cultivated plain belonging to the village of Malschen.

The basalt is of a dark grayish black, very fine-grained in the fracture, and contains very numerous but very small crystals of pyroxene. There is no visible trace of magnetic ironstone, which is always distinguished by its metallic lustre. Its polarity is remarkable, being so great that the needle at the eastern foot of the basalt rock is moved $40^{\circ}$, and at the cone itself $90^{\circ} \mathrm{W}$. At the western foot of the rock the contrary is the case; but this polarity is shown not only in the whole mass of the rock, but likewise in the larger detached pieces, and even in the smallest fragments, the north point of the needle being at one end distinctly attracted, and at the opposite end as distinctly repelled.

The same polarity I discovered on the Breitenberg, which rises to the south of the great Wostrai, about $10^{\circ}$ to $15^{\circ}$ higher, is entirely covered with high forest trees, and presents only on

* From Schweigger's Journal. 


\section{Dr. Turner on the Composition of Chloride of Barium.}

the eastern declivity detached low masses of rock, the nearer circumstances of which, respecting their position, are not known. Higher masses of rock project at the north-western declivity. The basalt forming them is also of a dark grayish black, somewhat coarser in the grain, but contains instead of pyroxene a great quantity of olivine, dispersed in very small grains of olive-green and bright vine-yellow colours. It also disturbs the magnetic needle, but less than that of the high Wostrai; and its polarity only shows itself when the needle is brought very close to the rock, whilst at the former it is moved at a much greater distance.

XXIX. On the Composition of Chloride of Barium. By Dr. Edward Turner, Professor of Chemistry in the University of London.*

I $\mathrm{N}$ taking a leview of the present state of chemistry ; - of the numerous compounds that have been discovered within a very limited period, and of which many have as yet been but partially or imperfectly examined;-of the results, often discordant, which analysts have obtained; - and of the opposite theoretic views which are prevalent, -it is difficult to avoid suspecting the propriety of opinions that have been thought to rest on the sure basis of correct observation, or doubting the accuracy of analyses conducted by chemists of the highest reputation. The æra of brilliant discovery in chemistry appears to have terminated for the present. The time is arrived for reviewing our stock of information, and submitting the principal facts and fundamental doctrines of the science to the severest scrutiny. The activity of chemists should now, I conceive, be especially employed, not so much in searching for new compounds or new elements, as in examining those already discovered; in ascertaining with the greatest possible care the exact ratio in which the elements of compounds are united; in correcting the erroneous statements to which inaccurate observation has given rise; and exposing the fallacy of opinions which partial experience or false facts have produced. Considerable as is the labour and difficulty of such researches, they will eventually prove of great importance to chemical science by supplying correct materials for reasoning; and will sometimes, even in the most familiar parts of analytical che-

- From the Philosophical Transactions for 1829, part ii. Although some time has now elapsed since the publication of this paper, we still think it right to transfer it to our pages, on account of the connection of the subject with those of several communications inserted at various recent periods in the Phil. Mag. and Annals.-Enit.

mistry, 